\title{
The importance of riparian forests and tree plantations for the occurrence of the European Turtle Dove Streptopelia turtur in an intensively cultivated agroecosystem
}

\author{
GIANPASQUALE CHIATANTE* (D, ZENO PORRO and ALBERTO MERIGGI \\ Department of Earth and Environmental Sciences, University of Pavia, Via Adolfo Ferrata \\ 1, 27100 Pavia, Italy. \\ *Author for correspondence; email: gp.chiatante@gmail.com
}

(Received 7 February 2019; revision accepted II September 2019)

\section{Summary}

Farmland birds represent a large proportion of European avifauna, and the populations of several species have suffered a dramatic decline in recent decades. Among these species, the European Turtle Dove Streptopelia turtur has undergone rapid decline in much of its European range. Therefore, the main aims of this research are to estimate the population density of the Turtle Dove and to investigate its habitat use at home range scale in an intensively cultivated agroecosystem in northern Italy. In the 2015 breeding season we carried out turtle dove counts from 372 point-counts, randomly allocated following a stratified cluster sampling design. The density was estimated by distance sampling, whereas the habitat suitability was assessed by Resource Selection Probability Function. In particular, we followed a presence vs availability approach, using binary logistic regression and the Information-Theoretic approach. During fieldwork, 76 observations of Turtle Dove were collected and a density of 5.0 pairs $/ \mathrm{km}^{2}$ was estimated. The Turtle Dove inhabits areas with high tree cover, either semi-natural forests or tree plantations, as well as areas with many shrubs and hedgerows. On the other hand, areas with a high proportion of crops, such as paddyfields, maize, and winter cereals are avoided. For the species' conservation, it is necessary to maintain a combination of habitat features with suitable nesting and feeding areas, as the degradation of either of these may reduce Turtle Dove populations.

Keywords: Streptopelia turtur, habitat selection, distance sampling, farmland birds, poplar plantations

\section{Introduction}

Farmland bird species represent a large proportion of European avifauna, and the populations of several species have suffered a dramatic decline in recent decades, especially in Western Europe (Donald et al. 2001, 2002). The causes of this decline have been identified mostly in the changes of agricultural practices, such as heavy mechanization, increased fertilizer inputs, and a temporal shift in cereal sowing from spring to autumn. In addition, the intensification of agricultural practices and 
the consequent loss of landscape heterogeneity, determined by the destruction of hedgerows, shrubs, tree patches, and other natural areas, is also a major threat (Fuller et al. 1995, Donald et al. 2002, Benton et al. 2003, Newton 2004). These changes have led to both the reduction of refuge and breeding sites and to a decrease in invertebrate prey, prompted as well by the increase in biocide use (Wilson et al. 1999, Benton et al. 2002, Boatman et al. 2004, Brambilla 2019). A further cause of farmland species decline is represented by land abandonment (Donald et al. 2002, SuárezSeone et al. 2002, Rippa et al. 2011), which is now threatening important farmland bird populations in mountain areas (Brambilla et al. 2010). To make safeguarding agro-ecosystems and their dependent species possible, a set of agri-environmental policies (AEPs) has been initiated. Targeting is therefore required, to direct agri-environment funding to those areas and actions which will provide the greatest environmental results (Webster and Felton 1993, Thompson et al. 1999). Consequently, knowledge of the distribution and characterization of the selected species' habitats is essential to achieving this goal and, hence, species' conservation and management planning.

The European Turtle Dove Streptopelia turtur (hereafter Turtle Dove) is a long-distance migratory farmland bird. Typically associated with woodland edges, it inhabits a wide variety of lowland habitats, with a mosaic of open ground and wooded or shrubby areas (Cramp 1985, Gibbs et al. 2001). However, in the absence of natural arboreal vegetation, as in intensively cultivated agroecosystems, the Turtle Dove also nests in orchards, i.e. olive and citrus groves, as happens in southern Italy (Chiatante and Meriggi 2016), Greece (Solomou and Sfougaris 2015), and North Africa (Hanane and Baamal 2011, Yahiaoui et al. 2014). The Turtle Dove has undergone a rapid decline in much of its European range, where it has decreased by $30-49 \%$ in 16 years (BirdLife International 2017, PECBMS 2019), as highlighted also by the recent international Action Plan for the species (Fisher et al. 2018). In some countries the species has suffered a severe decline, greater than $80 \%$, as in Belgium, Finland, Netherlands, European Russia, and United Kingdom (BirdLife International 2015, 2017). For this reason it is listed as 'Vulnerable' (BirdLife International 2015, 2017). The intensification of agriculture, including the transformation of the landscape, the simplification of crop rotation, the removal of hedgerows and other non-farmed features (e.g. ponds, woodlands, etc.), as well as the intensive use of fertilizers and pesticides, represent the main threats to the species. These changes can both reduce the food supply and nesting habitat availability (Browne and Aebischer 2004, BirdLife International 2017, Fisher et al. 2018). Overexploitation and illegal hunting, especially during migration and in the wintering grounds, are also significant threats (BirdLife International 2017, Fisher et al. 2018). Other threats include diseases, severe droughts in the Sahel, and the loss of suitable stop-over sites along migration routes (BirdLife International 2017, Fisher et al. 2018). On the other hand, climate change seems to be beneficial, at least in the northern part of its range, because of the expansion of suitable breeding areas (Harrison et al. 2003, Marx and Quillfeldt 2018), even if wintering grounds can lead to an abnormally high mortality rate because of increasing drought (Fisher et al. 2018).

In the light of this context, the main aims of this research were to estimate the population density of the Turtle Dove and to define its habitat requirements at home range scale in an intensively cultivated agroecosystem in northern Italy. We expected that the Turtle Dove would select sites with high woodland cover and hedgerow density, used likely for nesting. Moreover, we expected a negative effect of intensively cultivated crops, i.e. paddyfields and maize. These hypotheses derived from the knowledge of the general habits and ecology of the species (Cramp 1985, Gibbs et al. 2001). There are many reasons that make this research relevant. Considering the strong decline of its populations and its conservation importance, it is vital to carry out research concerning the ecology of this species in Europe, especially because it holds $25-49 \%$ of the species' global population (BirdLife International 2017). Indeed, action 7.4.I "Improve knowledge of turtle-dove habitat selection and dietary needs" of the International Action Plan for the species is considered essential (Fisher et al. 2018). This is true particularly in Priority Intervention Areas for the species' conservation, as is most of the Italian territory (PECBMS 2019). In Italy, where 150,000-300,000 pairs are estimated ( $5 \%$ of European population), the population trend is unknown both in the short and in the long-term (BirdLife International 2017) and the Turtle Dove is listed as SPEC1, a 
European species of global conservation concern (BirdLife International 2017), with an unfavourable conservation status (Gustin et al. 2016). However, to our knowledge there is no other research on this species in Italy, and the few data available are derived from the grey literature or studies not focused on this species (Brichetti and Fracasso 2006). Furthermore, the Turtle Dove being a farmland species, our findings might help also to better understand the ecology of farmland birds in Italy (Brambilla 2019) and, more generally, in Europe, inasmuch they are decreasing sharply as previously stated.

\section{Materials and methods}

\section{Study area}

The present study was carried out in the western Po Plain (north-western Italy), in an area of about $2,900 \mathrm{~km}^{2}\left(45^{\circ} \mathrm{II} \mathrm{N}^{\prime} \mathrm{N}, 9^{\circ} \mathrm{O} 5^{\prime} \mathrm{E}\right)$ (Figure I). The Ticino River crosses the study area from north to south, flowing into the Po River that runs from west to east. The Sesia River and the Lambro River flow along the western and the eastern boundaries of the study area, respectively. The landscape is characterized by cultivated areas, especially paddy fields (39.4\%), other annual crops (mainly maize, soybean, oil-seed rape, winter wheat, and alfalfa) $(29.1 \%)$, and tree plantations $(6.8 \%)$. Broad-leaved forests and built-up areas represent $4.9 \%$ and $10.3 \%$ of the total area, respectively. The data used to measure the land use cover were obtained from the regional land use map "DUSAF 5.0" (ERSAF 2015) and from the regional forest map "Carta dei tipi forestali reali della Lombardia" (ERSAF 2012), and processed by the software Quantum GIS v.3.2.3 'Bonn'. Continuous forests (composed mainly of Quercus robur, Carpinus betulus, willow Salix sp., poplar Poplar sp., and the invasive Robinia pseudoacacia) are located along the Ticino River and in the southern part of the study area, near the Apennine slopes, whereas remnants of broad-leaved forest

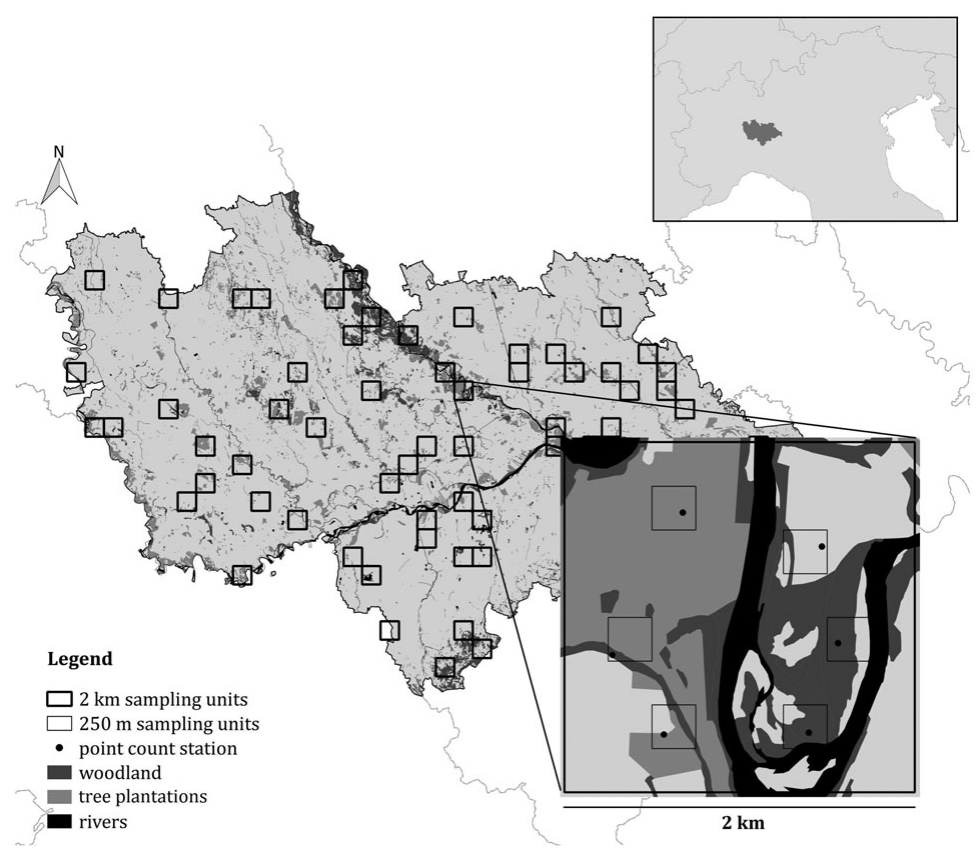

Figure 1 . The survey design used in the study. Both the $2 \mathrm{~km}$ and the $250 \mathrm{~m}$ sampling units are shown, as well as the point count stations. The location of the study area in northern Italy is shown in the insert. 
fragments are scattered in the cultivated area ( $95 \%$ of which are smaller than to ha). Tree plantations mainly consist of monospecific plantations of hybrid poplar species, but also of reforestations and short rotation coppices (SRCs). Due to its particular geographical location, this area is difficult to relate to other European lowlands. Even though the Po Plain has a subcontinental climate, it is separated from the rest of continental Europe by the Alps, which could act as a zoogeographical barrier (Bianco 1990, Hermansen et al. 2011). Furthermore, even if it is attributable to the Mediterranean Basin, the climate, land use, and vegetation in the Po Plain differ from the rest of the Mediterranean area (Mikusiński and Angelstam 1997, Capotorti et al. 2012).

\section{Survey design and data collection}

In order to obtain a representative sample in this large and heterogeneous study area, a stratified cluster sampling design was performed (Krebs 1999, Sutherland et al. 2004, Sutherland 2006, Barabesi and Fattorini 2013). According to this approach, the area was firstly divided in Landscape Units (LUs), i.e. homogeneous portions of the area in terms of habitat or ecological characteristics likely to induce systematic variations in population density (Sutherland 2006). To this aim, a $2 \times$ $2 \mathrm{~km}$ grid of sampling cells was superimposed on the study area and each cell was assigned to a LU, based on its characteristics. More details on LU definition are reported in Appendix $\mathrm{S}_{1}$ in the online Supplementary Materials. Data were collected in 62 randomly selected sampling cells (approximatively $10 \%$ of the study area). The number of sampling cells selected for each LU was proportional to the LU extent, in such a way that all the landscape characteristics of the study area were represented and each stratum was investigated with an effort proportional to its extent (Krebs 1999). Within each selected sampling cell six point-counts were carried out (Bibby et al. 2000, Sutherland 2006) during the breeding season 2015, between May and early June, the peak of the singing and breeding activity (Cramp 1985, Brichetti and Fracasso 2006). Data on species occurrence were therefore collected in 372 point-counts. The selection of the six point counts inside the $2-\mathrm{km}$ cell was carried out by multi-level sampling (Sutherland 2006), subdividing the $2-\mathrm{km}$ cells into cells of $250 \times 250 \mathrm{~m}$ and randomly selecting six of them (Figure $\mathrm{I}$ ). Using this second grid, it was possible to obtain estimates that are more precise. Each point, placed randomly inside the cells, was surveyed once from dawn to 10:30, and the count lasted for 10 minutes (Chamberlain and Rolando 2014); overall, data collection took place for 32 effective days. During the fieldwork, we measured the exact distance from the observer to the birds with a laser rangefinder (Leica Rangemaster 900; Leica, Solms, Germany). When we did not see a calling bird, we mapped its approximate position on aerial photographs (1:5,000 scale) based on the likely attenuation and direction of its vocalization. We then measured the distance from observer to the position of each calling bird using the software QGIS v.3.2.3 'Bonn'.

\section{Density estimation}

The density of the species was estimated through the distance sampling method using the software Distance 7.2 (Buckland et al. 1993, 2001, Thomas et al. 2010). For density estimation, we used only the first detection of each located individual or pair, as suggested by Buckland et al. (2001). After a visual inspection of distance distribution, we truncated 10\% of the largest observations as suggested by Buckland et al. (1993) and transformed the distance data into equal intervals of $60 \mathrm{~m}$. We chose these intervals because they were the best for assuring a good shape of the distance data, inasmuch as shape criterion is one of the main assumption of distance sampling (Buckland et al. 1993). We tested various combinations of key functions (uniform, half-normal) and series adjustments (cosine, simple polynomial, Hermite polynomial) (Buckland et al. 1993) and we used the Akaike Information Criterion (AIC) (Akaike 1973) to evaluate the fit of each model (Buckland et al. 1993, Thomas et al. 2010). Among the models with the lowest AIC values, the one that appeared most suitable based on a visual examination of histograms and the results of $\chi^{2}$ goodness-of-fit tests was selected (Buckland et al. 2001, Buckland 2006, Thomas et al. 2010). Furthermore, the average 
Table 1. Environmental variables used to investigate the habitat selection of the European Turtle Dove in northern Italy. Mean $( \pm S E)$, minimum, and maximum values of each variables in the hexagonal grid superimposed on the study area were reported.

\begin{tabular}{lrr}
\hline Environmental variables & mean \pm SE & min - max \\
\hline Built-up areas (\%) & $9.6 \pm 0.075$ & $0.0-100.0$ \\
Cereal crops (e.g. winter wheat, barley) (\%) & $5.8 \pm 0.056$ & $0.0-100.0$ \\
Maize (\%) & $11.0 \pm 0.077$ & $0.0-100.0$ \\
Paddyfields (\%) & $32.7 \pm 0.130$ & $0.0-100.0$ \\
Fodder crops (e.g. alfalfa, clover) (\%) & $4.5 \pm 0.050$ & $0.0-100.0$ \\
Industrial crops and legumes (e.g. rape, soybean) (\%) & $4.6 \pm 0.052$ & $0.0-100.0$ \\
Horticulture (\%) & $0.8 \pm 0.022$ & $0.0-100.0$ \\
Vineyards (\%) & $2.4 \pm 0.041$ & $0.0-100.0$ \\
Poplar plantations (\%) & $6.0 \pm 0.061$ & $0.0-100.0$ \\
Other tree plantations (i.e. reforestations, SRCs) (\%) & $0.6 \pm 0.019$ & $0.0-100.0$ \\
Meadows without shrubs and trees (\%) & $2.6 \pm 0.035$ & $0.0-100.0$ \\
Oak Quercus sp. forests (\%) & $1.0 \pm 0.026$ & $0.0-100.0$ \\
Willow Salix sp. riparian forests (\%) & $0.7 \pm 0.018$ & $0.0-100.0$ \\
Black Locust Robinia pseudoacacia forests (\%) & $0.8 \pm 0.017$ & $0.0-100.0$ \\
Shrublands (\%) & $1.2 \pm 0.022$ & $0.0-100.0$ \\
Fallows (\%) & $1.4 \pm 0.021$ & $0.0-100.0$ \\
Rivers and water bodies (\%) & $1.7 \pm 0.033$ & $0.0-100.0$ \\
Hedgerows density (m/ha) & $12.93 \pm 0.081$ & $0.0-294.53$ \\
\hline
\end{tabular}

probability of detection was estimated, and the effective detection radius (EDR) was defined. For each estimate the percentage coefficient of variation $(\mathrm{CV})$ and the $95 \%$ confidence intervals (CI) were calculated.

\section{Habitat suitability}

The habitat requirements of the Turtle Dove were evaluated following a presence vs. availability approach (Boyce et al. 2002, Manly et al. 2002). The environmental variables (Table I) were measured at the home-range scale (Manly et al. 2002, Morrison et al. 2006) at presence sites and subsequently compared with those of an equal number of availability sites which were randomly selected in the study area without any constraints (Boyce et al. 2002, Manly et al. 2002, Keating and Cherry 2004). By considering the relevance of taking into account the spatial ecology of the species (Brennan et al. 2002, Manly et al. 2002), presence/availability sites corresponded to cells whose extent was defined based on the home range size of the species during breeding, as suggested by the available literature. Specifically, the home range of the species is equal to 1.91-3.08 ha (Browne and Aebischer 2004), hence, considering an average of about 2.5 ha, a grid was generated with hexagonal cells with this area (Caprio et al. 2011, Boan et al. 2014). Subsequently, in order to investigate the relationships between the environmental variables and the Turtle Dove, we tested for significant difference between presence and random sites using the non-parametric Mann-Whitney $U$ test (Legendre and Legendre 1998). Then, a Resource Selection Probability Function was formulated (Boyce et al. 2002, Manly et al. 2002) performing a generalized linear model with a binomial error distribution (Keating and Cherry 2004, Rushton et al. 2004). In particular, a priori sets of models were first built using all the combination of the environmental variables that seemed to affect species occurrence. For each model the secondorder Akaike Information Criterion $\left(\mathrm{AIC}_{\mathrm{c}}\right.$ ) was calculated and the model with the lower $\mathrm{AIC}_{\mathrm{c}}$ was selected as the best (Anderson and Burnham 2002, Burnham and Anderson 2002). However, considering that models with $\Delta \mathrm{AIC}_{\mathrm{c}} \leq 2$ give substantial support (Burnham and Anderson 2002), we showed and discussed them also. For the analysis, all variables considered were standardized by normalization, that is, each variable had a mean of zero and a standard deviation of one 
(Quinn and Keough 2002, Zuur et al. 2007). The model's ability to distinguish between occupied and available sites was tested by means of the area under the curve (AUC) of the Receiver Operating Characteristic plot (ROC curve) (Pearce and Ferrier 2000, Fawcett 2006). Moreover, we tested both the residuals' normality by the Kolmogorov-Smirnov test (Legendre and Legendre 1998) and the residuals' spatial autocorrelation by the Moran I test (Zuur et al. 2007, Bivand et al. 2008). We used the Variance Inflation Factor (VIF) with a threshold of 3 to exclude variables' collinearity (Fox and Monette 1992, Zuur et al. 2010). The explained deviance $D^{2}$ was used as a measure of the variance explained by the model (Crawley 1993, Zuur et al. 2007).

Data used to measure the environmental variables were obtained from the regional land use map "DUSAF 5.0" (ERSAF 2015) and from the regional forest map "Carta dei tipi forestali reali della Lombardia" (ERSAF 2012) and processed by the software Quantum GIS v.3.2.3 'Bonn'. All the analyses were performed using the statistical software R v.3.3.2 (R Core Team 2019) and the packages MuMIn (Tillé and Matei 2016), car (Fox and Weisberg 2011), and ROCR (Sing et al. 2007).

\section{Results}

\section{Density estimation}

During fieldwork, 76 observations of Turtle Dove were collected, at an average distance of $113 \mathrm{~m}$ $(\mathrm{SE}=9.0, \mathrm{~min}=\mathrm{o} \mathrm{m}, \max =363 \mathrm{~m}$ ), but six of them were removed from the analysis because of the right truncation. The best detection probability function obtained was the uniform + cosine with two parameters $\left(\mathrm{AIC}=179.57, \chi^{2}=0.389, \mathrm{df}=1.0, P=0.533\right.$ ) (Table 2). This gave an EDR of $107 \mathrm{~m}$ and the average probability of detection was estimated to be $0.20\left(\mathrm{CV}=14.0 \%\right.$; $95 \% \mathrm{CI}=0.15^{-}$ o.26). Single birds or pairs were usually observed, with an average of $1.04 \pm 0.01$ (SE) ind/group. There was no correlation between group size and distances of detection $(\mathrm{r}=0.181, \mathrm{df}=68, P=$ 0.934). The density of Turtle Doves estimated was 5.0 pairs $/ \mathrm{km}^{2}(\mathrm{SE}=0.01, \min =3.7, \max =7.7$, $\mathrm{CV}=18.6 \%$ ) (Figure 2 ).

\section{Habitat suitability}

The analyses showed that there were some differences between presence and availability sites (Table 3). In particular, in the presence sites there was a greater cover of poplar plantations and other tree plantations, oak forests, riparian willow forests, and shrublands, than in the availability sites. In contrast, there was also a lesser cover of maize and paddy fields. The best model showed that density of poplar plantations, riparian willow forests, shrublands, and hedgerows positively affected the presence of the Turtle Dove (Figure 3, Table 4). On the contrary, built-up areas, cereal crops, maize, and paddy fields negatively influenced the presence of the species. The set of the best models (ESM Table SI) showed that another three variables positively affected the presence of the Turtle Dove, though they were less important. Specifically, other tree plantations, oak forests, and Robinia pseudoacacia forests. The ability of the best model to distinguish between occupied and

Table 2. Models obtained by distance sampling for the density estimation of European Turtle Dove in northern Italy. The number of parameters (k), AIC values, densities estimations (D), and their standard errors (SE), $95 \%$ confidence intervals (95\% CI) and coefficients of variation (CV) were showed. Densities are shown as pairs $/ \mathrm{km}^{2}$.

\begin{tabular}{lcccccc}
\hline Model (key function + series adjustment) & $\mathrm{k}$ & $\mathrm{AIC}$ & $\Delta \mathrm{AIC}$ & $\mathrm{D} \pm \mathrm{SE}$ & $95 \% \mathrm{CI}$ & $\mathrm{CV}$ \\
\hline Uniform + cosine & 2 & 179.57 & 0.00 & $5.4 \pm 0.01$ & $3.7-7 \cdot 7$ & $18.6 \%$ \\
Uniform + simple polynomial & 3 & 181.29 & 1.72 & $5.2 \pm 0.02$ & $3.0-9.2$ & $29.3 \%$ \\
Half-normal + cosine & 1 & 180.22 & 0.65 & $5.0 \pm 0.01$ & $3.5-7.1$ & $18.3 \%$ \\
Half-normal + Hermite polynomial & 1 & 180.22 & 0.65 & $5.0 \pm 0.01$ & $3.5-7.1$ & $18.3 \%$ \\
\hline
\end{tabular}




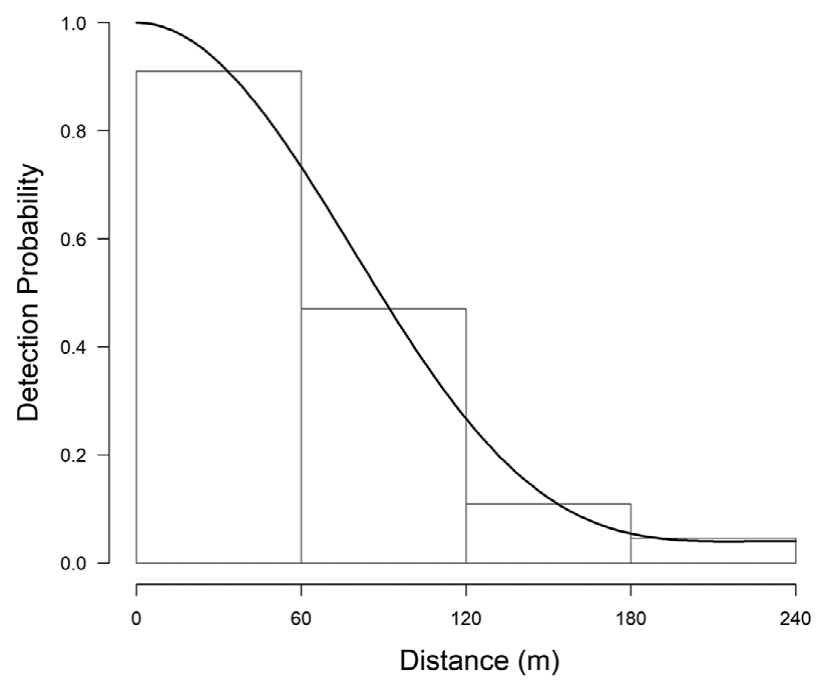

Figure 2. Histograms of the detection functions calculated to estimate the density of the European Turtle Dove. On the $\mathrm{x}$-axis the detection distance in meters, on the y-axis the detection probability (from o to 1 ).

unoccupied sites was good, with an area under the ROC curve equal to $0.832(P<0.001)$. The model residuals were normally distributed $(\mathrm{D}=0.053, P=0.726)$ and did not show any spatial correlation (Moran test, $I=0.484, P=0.314$ ). The VIF revealed no collinearity among predictors (Table 4 ) and the explained deviance $D^{2}$ was equal to $26.4 \%$. The study area showed an average predicted probability of $0.49 \pm 0.008$ (SE) (min. 0.05, max 1.0) (Figure S2).

\section{Discussion}

Our analyses showed that breeding densities of the Turtle Dove in the agroecosystem investigated are between 3.7 and 7.7 pairs $/ \mathrm{km}^{2}$, with an average of 5.0 pairs $/ \mathrm{km}^{2}$. These densities are similar or slightly higher than other densities observed in northern Italy, where $1-5$ pairs $/ \mathrm{km}^{2}$ were estimated (Brichetti and Fracasso 2006). Unfortunately, due to the small sample size, we could not estimate densities for each land use type, therefore our estimate is related to the whole study area. However, in general the densities are lower in farmlands than in woodlands (Fisher et al. 2018). Indeed, in Spanish farmlands, 5 pairs $/ \mathrm{km}^{2}$ were estimated (Sáenz De Buruaga et al. 2012), whereas in English farmlands the densities estimated are lower (0.4-4.3 pairs $/ \mathrm{km}^{2}$; Browne and Aebischer 2004). On the other hand, densities in areas with higher woodland cover in Spain comprised between 10 and 26 males $/ \mathrm{km}^{2}$ (Sáenz De Buruaga et al. 2012). On the other hand, our estimates are largely lower than those observed in North Africa, where 45 pairs/ha were estimated in citrus groves (Brahmia et al. 2015); besides, in Moroccan olive groves 16-20 nests/ha were estimated (Hanane and Baamal 201I). The relatively high densities estimated could be partially explained by the average detection probability of 0.20 , quite low with respect to the value of 0.56 found in another study (Johnston et al. 2014). However, this low detection could be explained by at least two reasons. First, in our study most of the observations referred to closed habitat types, such as forests, shrublands, and tree plantations, where lower detectability is the rule (Buckland et al. 1993, Gottschalk and Huettmann 2011, Johnston et al. 2014). Second, we observed Turtle Doves also in very heterogeneous landscapes with small patches of forests and it is known that detection probability declined with increasing forest fragmentation (De Wan et al. 2009). 

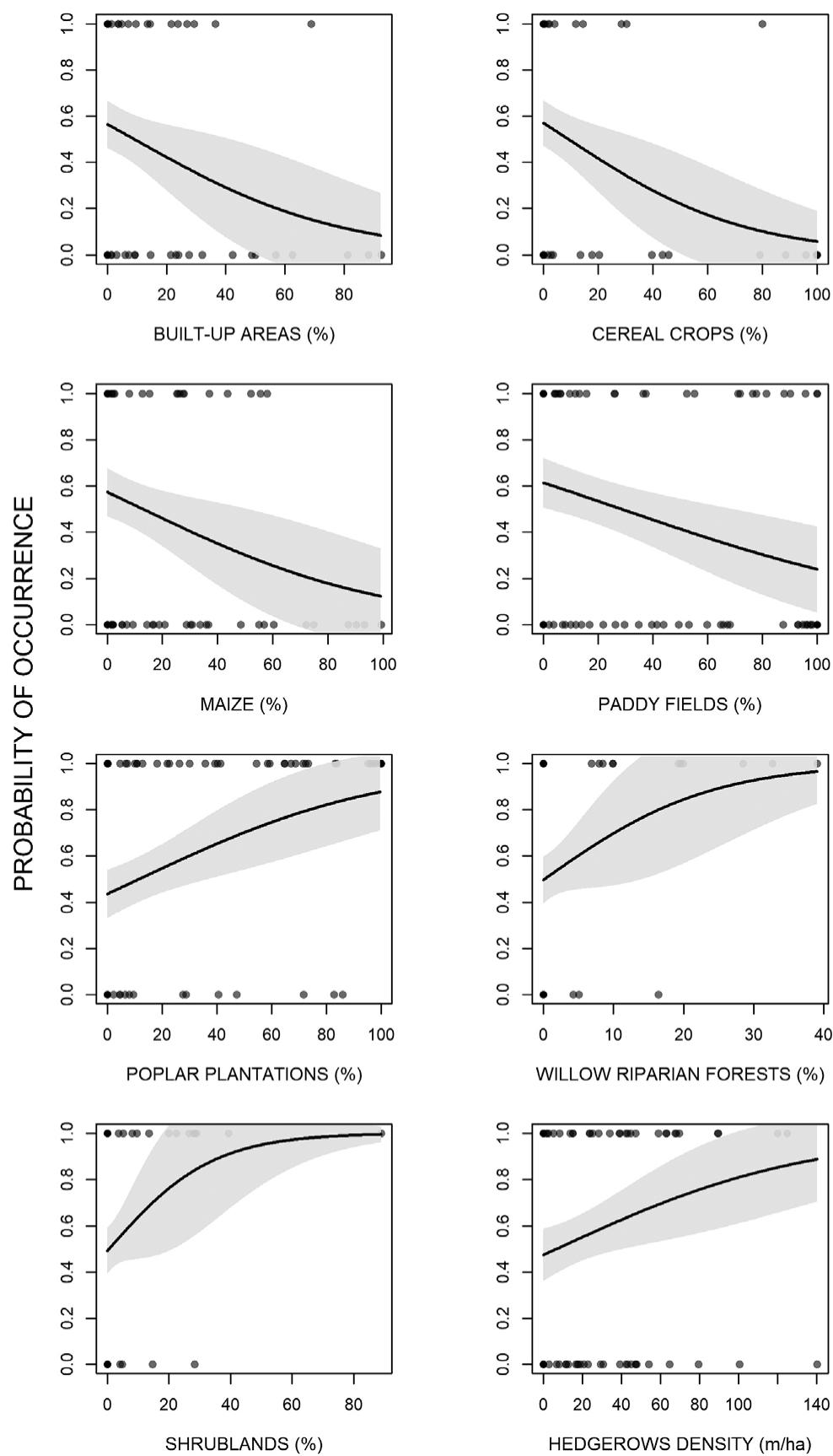

Figure 3. Effects of the environmental variables on the occurrence of the European Turtle Dove in northern Italy. 
Table 3. Mean values ( \pm SE) of the environmental variables measured in the presence and in the random sites. We highlighted in bold the variables for which we found significant differences $(\mathrm{P}<0.05)$ by the nonparametric Mann-Whitney $U$ test.

\begin{tabular}{lcrr}
\hline Environmental variables & presence & random & P \\
\hline Built-up areas (\%) & $3.1 \pm 0.76$ & $8.3 \pm 1.55$ & 0.125 \\
Cereal crops (e.g. winter wheat, barley) (\%) & $2.0 \pm 0.74$ & $10.0 \pm 2.06$ & 0.085 \\
Maize (\%) & $\mathbf{4 . 9} \pm \mathbf{0 . 9 9}$ & $\mathbf{1 2 . 4} \pm \mathbf{1 . 9}$ & $\mathbf{0 . 0 3 0}$ \\
Paddyfields (\%) & $\mathbf{1 3 . 4} \pm \mathbf{2 . 1 6}$ & $\mathbf{3 1 . 6} \pm \mathbf{3 . 1 3}$ & $\mathbf{0 . 0 0 2}$ \\
Fodder crops (e.g. alfalfa, clover) (\%) & $2.0 \pm 0.62$ & $4.2 \pm 1.11$ & 0.802 \\
Vineyards (\%) & $1.5 \pm 0.63$ & $\mathbf{2 . 9} \pm 1.10$ & 0.852 \\
Poplar plantations (\%) & $\mathbf{2 7 . 0} \pm \mathbf{2 . 8 6}$ & $\mathbf{4 . 9} \pm \mathbf{1 . 2 6}$ & $\mathbf{0 . 0 0 1}$ \\
Other tree plantations (i.e. reforestations, SRCs) (\%) & $\mathbf{4 . 7} \pm \mathbf{1 . 2 1}$ & $\mathbf{1 . 5} \pm \mathbf{0 . 7 6}$ & $\mathbf{0 . 0 2 1}$ \\
Meadows without shrubs and trees (\%) & $\mathbf{2 . 9} \pm 0.74$ & $\mathbf{1 . 4} \pm 0.59$ & 0.233 \\
Oak (Quercus sp.) forests (\%) & $\mathbf{7 . 1} \pm \mathbf{1 . 5 0}$ & $\mathbf{2 . 1} \pm \mathbf{1 . 0 4}$ & $<\mathbf{0 . 0 0 1}$ \\
Willow (Salix sp.) riparian forests (\%) & $\mathbf{2 . 3} \pm \mathbf{0 . 5 5}$ & $\mathbf{0 . 3} \pm \mathbf{0 . 1 5}$ & $\mathbf{0 . 0 2 5}$ \\
Black Locust Robinia pseudoacacia forests (\%) & $2.9 \pm 0.78$ & $\mathbf{1 . 3} \pm 0.51$ & 0.072 \\
Shrublands (\%) & $\mathbf{3 . 7} \pm \mathbf{0 . 9 3}$ & $\mathbf{0 . 6} \pm \mathbf{0 . 2 7}$ & $\mathbf{0 . 0 2 2}$ \\
Fallows (\%) & $1.2 \pm 0.39$ & $0.3 \pm 0.11$ & 0.074 \\
Hedgerows density (m/ha) & $14.6 \pm 2.15$ & $\mathbf{1 1 . 5} \pm 1.87$ & 0.610 \\
\hline
\end{tabular}

Table 4. The best model explained the habitat requirement of the European Turtle Dove in northern Italy. The estimate $(\beta)$, the standard error (SE), the lower (LCI) and upper (UCI) $95 \%$ confidence intervals, and the Variance Inflation Factors (VIF) were shown.

\begin{tabular}{lcccrr}
\hline Environmental variables & $\beta$ & SE & LCI & UCI & VIF \\
\hline intercept & 0.098 & 0.201 & - & - & - \\
Built-up areas & -0.464 & 0.217 & -0.953 & -0.083 & 1.077 \\
Cereal crops & -0.635 & 0.259 & -1.258 & -0.196 & 1.139 \\
Maize & -0.458 & 0.204 & -0.900 & -0.085 & 1.102 \\
Paddy fields & -0.587 & 0.209 & -1.015 & -0.191 & 1.285 \\
Poplar plantations & 0.692 & 0.255 & 0.232 & 1.251 & 1.143 \\
Willow (Salix sp.) riparian forests & 0.458 & 0.289 & 0.003 & 1.223 & 1.014 \\
Shrublands & 0.544 & 0.345 & 0.004 & 1.411 & 1.082 \\
Hedgerows density & 0.409 & 0.189 & 0.051 & 0.802 & 1.117 \\
\hline
\end{tabular}

Concerning its habitat requirements, the Turtle Dove selects semi-natural forests, especially riparian willow forests but also oak-dominated forests. Certainly, the species regularly inhabits forests, both broadleaved and needleleaved, as well as mixed (Browne and Aebischer 2003, Browne et al. 2005, Bakaloudis et al. 2009, Dias et al. 2013, Marx and Quillfeldt 2018). This is a rule not only in Central Europe, but also in North Africa, where the subspecies S. t. arenicola is also distributed (Yahiaoui et al. 2014, Hanane and Yassin 2017, Hanane 2018). The selection of riparian forests by the Turtle Dove is already known (Sáenz De Buruaga et al. 2012, Gruychev and Mihaylov 2019), although in some studies the distance from open water was not relevant (Gutiérrez-Galán et al. 2018, Hanane 2018). As pointed out by Hanane (2018), this fact could be explained by the ability of the species to travel long distances to reach water points, or by the fact that other factors are more limiting. In our study area, however, we need to consider that a large proportion of wooded areas are placed along the Ticino River, therefore there could be some spatial dependence in relation to forests. In our study area, there is some evidence that Turtle Doves also inhabit sites with high cover of black locust. This fact could be due to the less dense structure of this tree, which might be favorable for the species; indeed, in Morocco there was evidence of the fact that the species does not tolerate a very enclosed microhabitat (Hanane 2018). However, 
considering its statistical weakness, it is reasonable to think that this finding is a random result, especially because black locust is often associated with oaks in our study area. As well as seminatural forests, shrublands and hedgerows have a positive effect on the species' presence. Past research has demonstrated that shrubs are very important for the species because nests are very often concealed inside them (Mason and MacDonald 2000, Browne et al. 2005, Dunn and Morris 2012). In particular, it was estimated that the most suitable should be $4.5 \mathrm{~m}$ high and $3 \mathrm{~m}$ wide (Sparks et al. 1996, Browne et al. 2004). Nonetheless, in the Ebro valley (northern Spain), the abundance of the species is negatively associated with shrublands (Sáenz De Buruaga et al. 2012). Furthermore, hedgerows are undoubtedly very important in other parts of its range (Browne and Aebischer 2004, Browne et al. 2005, Dunn and Morris 2012, Dias et al. 2013) and their removal from farmland is one of the reasons for its decline in England (Browne et al. 2004). Generally, the most used are composed of thorny species like hawthorn Crataegus monogyna and blackthorn Prunus spinosa (Browne et al. 2005). In addition, the importance of hedgerows could be due to the presence of weeds along these linear features. Indeed, it is well known that one of the main habitat requirements for the species is weed-rich areas (Mason and MacDonald 2000, Browne and Aebischer 2003, Dunn et al. 2015, 2018). This is true because the diet of both adult and juveniles is often composed of seeds of wild species, especially common fumitory Fumaria officinalis and common chickweed Stellaria media (Murton et al. 1984, Gutiérrez-Galán and Alonso 2016, Dunn et al. 2017). The Turtle Dove also selects sites with high cover of tree plantations, such as poplar plantations and reforestations/SRCs. Notably, poplar plantations are selected in spite of the completely absence of shrubby understorey. In fact, in Portugal the species is positively affected by coniferous forests without understorey, probably because they provide a suitable combination of secure nesting sites and food resources in the herbaceous understorey (Dias et al. 2013). In our case, however, poplar plantations are likely not used as nesting sites because their structure is not very dense and therefore cannot provide safe shelter, but it is possible that they are used as feeding sites, as in Portugal. On the other hand, the positive selection for reforestations/SRCs is already known for the species in the study area (Chiatante et al. 2019). This land cover type could be used for nesting because it is often dense and thick, becoming a safe place in which build the nest.

As expected, paddy fields and maize have a negative effect on the Turtle Dove because of their unsuitability. Likewise, we found a negative effect of cereals on the Turtle Dove, which concurs with other research (Browne and Aebischer 2003, 2004). Our research was focused on the first part of the breeding period, so the under-use of cereals is to be expected because Turtle Doves use this habitat only after harvest (Browne and Aebischer 2003). In addition, the species is prone to extinction in arable lands where barley increased (Chamberlain and Fuller 2000). However, cultivated crops, principally wheat, barley, and oil-seed rape, often form the bulk of the diet of both adult and the nestlings (Browne and Aebischer 2002, Mansouri et al. 2019), and some studies have pointed out the importance of cereal crops for improving the number of chicks hatched and fledged per nest (Kafi et al. 2015, Mansouri et al. 2019). Undoubtedly, the presence of useful crops is important for the Turtle Dove, but probably not so much as the presence of weed-rich areas, especially in intensively cultivated agroecosystems, where the absence of fallows could be a limiting factor (Browne and Aebischer 2002, 2003). Finally, in our study area the Turtle Dove lives in sites with few built-up areas, which is in accordance with other researches carried out in the Iberian Peninsula and Morocco (Patón et al. 2012, Hanane 2018).

\section{Conclusion}

In summary, in an intensively cultivated agro-ecosystem in northern Italy, the Turtle Dove has densities of 5.0 pairs $/ \mathrm{km}^{2}$; however, considering the low detectability (equal to 0.20 ) this estimate could be biased (MacKenzie et al. 2006). This species inhabits areas with higher tree cover, either semi-natural forests or tree plantations, as well as areas with many shrubs and hedgerows, that are likely used for nesting. In addition, it avoids areas with a high proportion of crops, such as paddy fields, maize, and cereals. Furthermore, we point out the importance of maintaining weed-rich areas, 
such as hedgerows, which provide food both for adults and for juveniles. We have to keep in mind that these landscape features should also be maintained in areas in which there are no trees, shrubs, or hedgerows suitable for nesting, because the Turtle Dove can fly for many kilometres to reach feeding areas (Browne and Aebischer 2003, Gutiérrez-Galán et al. 2018). For conservation purposes, these should be encouraged also within or adjacent to cropped fields. They should be produced by sowing seed mixes that contain species eaten by Turtle Doves (Browne and Aebischer 2003, Dunn et al. 2015, Rocha and Quillfeldt 2015, Fisher et al. 2018). Besides, these landscape features should not be sprayed with herbicides or other pesticides because of the sensitivity of the species to biocides (Ruiz-Suárez et al. 2015, Fisher et al. 2018). Hence, Turtle Doves require a combination of habitat features with suitable nesting and feeding areas, both in close proximity and in the surrounding context of the home range, and the degradation of either of these may reduce Turtle Dove populations (Gillings and Fuller 1998, Browne et al. 2004, Dias et al. 2013, Fisher et al. 2018).

\section{Supplementary Materials}

To view supplementary material for this article, please visit http://dx.doi.org/10.1017/ So959270920000532.

\section{Acknowledgements}

We thank Arianna Musacchio, Arianna Bazzocchi, Kati Sara Bovo, and Jacopo Maria Santoro for the help on the fieldwork. We acknowledge Andrew Sturgeon for proofreading and providing linguistic advice. This research was conducted with ethical approval from the University of Pavia (Department of Earth and Environmental Sciences). Bird surveys were conducted with permission from local landowners where necessary. Data collection did not involve sampling procedure, and experimental manipulation of birds and the fieldwork was conducted under Law of the Republic of Italy on the Protection of Wildlife (February 25, 1992).

\section{References}

Akaike, H. (1973) Information theory as an extension of the maximum likelihood principle. Pp. 267-281 in B. N. Petrov and F. Csaki, eds. Second International Symposium on Information Theory. Budapest: Akademiai Kiado.

Anderson, D. R. and Burnham, K. P. (2002) Avoiding pitfalls when using informationtheoretic methods. J. Wildlife Manage. 66: 912-918.

Bakaloudis, D. E., Vlachos, C. G., Chatzinikos, E., Bontzorlos, V. and Papakosta, M. (2009) Breeding habitat preferences of the turtledove (Streptopelia turtur) in the Dadia-Soufli National Park and its implications for management. Eur. J. Wildlife Res. 55: 597-602.

Barabesi, L. and Fattorini, L. (2013) Random versus stratified location of transects or points in distance sampling: theoretical results and practical considerations. Environ. Ecol. Stat. 20: 215-236.
Benton, T. G., Bryant, D. M., Cole, L. and Crick, H. Q. P. (2002) Linking agricultural practice to insect and bird populations: a historical study over three decades: Farming, insect and bird populations. J. Appl. Ecol. 39: 673-687.

Benton, T. G., Vickery, J. A. and Wilson, J. D. (2003) Farmland biodiversity: is habitat heterogeneity the key? Trends Ecol. Evol. 18: 182-188.

Bianco, P. G. (1990) Potential role of the palaeohistory of the Mediterranean and Paratethys basins on the early dispersal of Euro-Mediterranean freshwater fishes. Ichthyol. Explor. Fres. 1: 167-184.

Bibby, C. J., Burgess, N. D., Hill, D. A. and Mustoe, S. H. (2000) Bird census techniques. 2nd Edition. London, UK: Academic Press.

BirdLife International (2015) European Red List of Birds. Luxembourg: Office for Official Publications of the European Communities. 
BirdLife International (2017) Streptopelia turtur: The IUCN Red List of Threatened Species 2017: e.T22690419A119457869.

Bivand, R., Pebesma, E. J. and Gómez-Rubio, V. (2008) Applied spatial data analysis with $R$. New York: Springer.

Boan, J. J., Malcolm, J. R. and McLaren, B. E. (2014) Forest overstorey and age as habitat? Detecting the indirect and direct effects of predators in defining habitat in a harvested boreal landscape. Forest Ecol. Manag. 326: 101-108.

Boatman, N. D., Brickle, N. W., Hart, J. D., Milsom, T. P., Morris, A. J., Murray, A. W. A., Murray, K. A. and Robertson, P. A. (2004) Evidence for indirect effects of pesticides on farmland birds. Ibis 146: 131-143.

Boyce, M. S., Vernier, P. R., Nielsen, S. E. and Schmiegelow, F. K. A. (2002) Evaluating resource selection functions. Ecol. Model. 157: 281-300.

Brahmia, H., Zeraoula, A., Bensouilah, T., Bouslama, Z. and Houhamdi, M. (2015) Breeding biology of sympatric Laughing Streptopelia senegalensis and Turtle Streptopelia turtur Dove: a comparative study in northeast Algeria. Zool. Ecol. 25: 220-226.

Brambilla, M. (2019) Six (or nearly so) big challenges for farmland bird conservation in Italy. Avocetta 43: N.2. DOI: https:// doi.org/I0.30456/AVO.2019201

Brambilla, M., Casale, F., Bergero, V., Bogliani, G., Crovetto, G. M., Falco, R., Roati, M. and Negri, I. (2010) Glorious past, uncertain present, bad future? Assessing effects of land-use changes on habitat suitability for a threatened farmland bird species. Biol. Conserv. 143: 2770-2778.

Brennan, J. M., Bender, D. J., Contreras, T. A. and Fahrig, L. (2002) Focal patch landscape studies for wildlife management: optimizing sampling effort across scales. Pp. 68-91 In J. Liu and W. W. Taylor Integrating landscape ecology into natural resource management. Cambridge: Cambridge University Press.

Brichetti, P. and Fracasso, G. (2006) Ornitologia Italiana. Vol 3 -Stercorariidae-Caprimulgidae. Bologna, IT: Alberto Perdisa editore.

Browne, S. J. and Aebischer, N. J. (2002) Temporal changes in the breeding and feeding ecology of Turtle Doves (Streptopelia turtur) in the UK: an overview. Z. Jagdwiss. 48: 215-221.
Browne, S. J. and Aebischer, N. J. (2003) Habitat use, foraging ecology and diet of Turtle Doves Streptopelia turtur in Britain. Ibis 145: 572-582.

Browne, S. J. and Aebischer, N. J. (2004) Temporal changes in the breeding ecology of European Turtle Doves Streptopelia turtur in Britain, and implications for conservation. Ibis 146: 125-137.

Browne, S. J., Aebischer, N. J. and Crick, H. Q. P. (2005) Breeding ecology of Turtle Doves Streptopelia turtir in Britain during the period 1941-2000: an analysis of BTO nest record cards. Bird Study 52: 1-9.

Browne, S. J., Aebischer, N. J., Yfantis, G. and Marchant, J. H. (2004) Habitat availability and use by Turtle Doves Streptopelia turtur between 1965 and 1995 an analysis of Common Birds Census data. Bird Study 51: 1-11.

Buckland, S. T. (2006) Point-transect surveys for songbirds: robust methodologies. The Auk 123: 345-357.

Buckland, S. T., Anderson, D. R., Burnham, K. P. and Laake, J. L. (1993) Distance sampling: estimating abundance of biological populations. London: Chapman \& Hall.

Buckland, S. T., Anderson, D. R., Burnham, K. P., Laake, J. L., Borchers, D. L. and Thomas, L. (2001) Introduction to distance sampling: estimating abundance of biological populations. New York: Oxford University Press.

Burnham, K. P. and Anderson, D. R. (2002) Model selection and multimodel inference: a practical information-theoretic approach. 2nd ed. New York: Springer.

Capotorti, G., Guida, D., Siervo, V., Smiraglia, D. and Blasi, C. (2012) Ecological classification of land and conservation of biodiversity at the national level: the case of Italy. Biol. Conserv. 147: 174-183.

Caprio, E., Chamberlain, D. E., Isaia, M. and Rolando, A. (2011) Landscape changes caused by high altitude ski-pistes affect bird species richness and distribution in the Alps. Biol. Conserv. 144: 2958-2967.

Chamberlain, D. and Rolando, A. (2014) The effects of a settling-down period on estimates of bird species richness and occurrence from point counts in the Alps. Bird Study 61: 121-124.

Chamberlain, D. E. and Fuller, R. J. (2000) Local extinctions and changes in species 
richness of lowland farmland birds in England and Wales in relation to recent changes in agricultural land-use. Agr. Ecosyst. Environ. 78: 1-17.

Chiatante, G., Giordano, M. and Meriggi, A. (2019) Bird diversity in short rotation coppice in Northern Italy. Ardea 107: 5-17.

Chiatante, G. and Meriggi, A. (2016) The importance of rotational crops for biodiversity conservation in Mediterranean areas. PLOS ONE 11: e0149323.

Cramp, S. (1985) Handbook of the birds of Europe, the Middle East and North Africa. Vol IV terns to woodpeckers. Oxford: Oxford University Press.

Crawley, M. J. (1993) GLIM for ecologists. Oxford: Blackwell Scientific Publications.

De Wan, A. A., Sullivan, P. J., Lembo, A. J., Smith, C. R., Maerz, J. C., Lassoie, J. P. and Richmond, M. E. (2009) Using occupancy models of forest breeding birds to prioritize conservation planning. Biol. Conserv. 142: 982-991.

Dias, S., Moreira, F., Beja, P., Carvalho, M., Gordinho, L., Reino, L., Oliveira, V. and Rego, F. (2013) Landscape effects on large scale abundance patterns of turtle doves Streptopelia turtur in Portugal. Eur. J. Wildlife Res. 59: 531-541.

Donald, P. F., Green, R. E. and Heath, M. F. (2001) Agricultural intensification and the collapse of Europe's farmland bird populations. Proc. R. Soc. London B 268: 25-29.

Donald, P. F., Pisano, G., Rayment, M. D. and Pain, D. J. (2002) The Common Agricultural Policy, EU enlargement and the conservation of Europe's farmland birds. Agr. Ecosyst. Environ. 89: 167-182.

Dunn, J. C. and Morris, A. J. (2012) Which features of UK farmland are important in retaining territories of the rapidly declining Turtle Dove Streptopelia turtur? Bird Study 59: 394-402.

Dunn, J. C., Morris, A. J. and Grice, P. V. (2015) Testing bespoke management of foraging habitat for European turtle doves Streptopelia turtur. J. Nat. Conserv. 25: 23-34.

Dunn, J. C., Morris, A. J. and Grice, P. V. (2017) Post-fledging habitat selection in a rapidly declining farmland bird, the European Turtle Dove Streptopelia turtur. Bird Conserv. Internatn. 27: 45-57.
Dunn, J. C., Stockdale, J. E., Moorhouse-Gann, R. J., McCubbin, A., Hipperson, H., Morris, A. J., Grice, P. V. and Symondson, W. O. C. (2018) The decline of the Turtle Dove: dietary associations with body condition and competition with other columbids analysed using high-througput sequencing. Mol. Ecol. 27: 3386-3407.

ESRAF (2012) Carta dei tipi forestali reali della Lombardia. Ente Regionale per i Servizi all'Agricoltura e alle Foreste (ESRAF). http://www.cartografia.regione.lombardia. it/metadata/ersaf/tipologie_forestali/doc/ relaz.pdf

ERSAF (2015) DUSAF 5.o. Ente Regionale per i Servizi all'Agricoltura e alle Foreste (ESRAF). https://www.dati.lombardia.it/

Fawcett, T. (2006) An introduction to ROC analysis. Pattern Recogn. Lett. 27: 861-874.

Fisher, I., Ashpole, J., Scallan, D., Proud, T. and Carboneras, C. (2018) International single species action plan for the conservation of the European Turtle-dove Streptopelia turtur (2018 to 2028). Luxembourg: European Commission.

Fox, J. and Monette, G. (1992) Generalized collinearity diagnostics. J. Am. Stat. Assoc. 87: $178-183$.

Fox, J. and Weisberg, S. (2011) Package car: an $R$ Companion to Applied Regression. Wien: www.cran.r-project.org.

Fuller, R. J., Gregory, R. D., Gibbons, D. W., Marchant, J. H., Wilson, J. D., Baillie, S. R. and Carter, N. (1995) Population decline and range contractions among lowland farmland birds in Britain. Conserv. Biol. 9: 1425-1441.

Gibbs, D., Barnes, E. and Cox, J. (2001) Pigeons and doves. A guide to the pigeons and doves of the world. London: Christopher Helm.

Gillings, S. and Fuller, R. J. (1998) Changes in bird populations on sample lowland English farms in relation to loss of hedgerows and other non-crop habitats. Oecologia 116: 120-127.

Gottschalk, T. K. and Huettmann, F. (2011) Comparison of distance sampling and territory mapping methods for birds in four different habitats. J. Ornithol. 152: 421-429.

Gruychev, G. and Mihaylov, H. (2019) Breeding density of European Turtle Dove (Streptopelia turtur) on Sakar Mountain (SE Bulgaria). Turk. J. Zool. 43: 403-406. 
Gustin, M., Brambilla, M. and Celada, C. (2016) Stato di conservazione e valore di riferimento favorevole per le popolazioni di uccelli nidificanti in Italia. Riv. Ital. Ornitol. 86: 3 .

Gutiérrez-Galán, A. and Alonso, C. (2016) European Turtle Dove Streptopelia turtur diet composition in Southern Spain: the role of wild seeds in Mediterranean forest areas. Bird Study 63: 490-499.

Gutiérrez-Galán, A., Sanchez, A. L. and González, C. A. (2018) Foraging habitat requirements of European Turtle Dove Streptopelia turtur in a Mediterranean forest landscape. Acta Ornithol. 53: 143.

Hanane, S. (2018) Multi-scale turtle dove nest habitat selection in a Mediterranean agroforestry landscape: implications for the conservation of a vulnerable species. Eur. J. Wildlife Res. 64: 45.

Hanane, S. and Baamal, L. (2011) Are Moroccan fruit orchards suitable breeding habitats for Turtle Doves Streptopelia turtur? Bird Study 58: 57-67.

Hanane, S. and Yassin, M. (2017) Nest-niche differentiation in two sympatric columbid species from a Mediterranean Tetraclinis woodland: Considerations for forest management. Acta Oecol. 78: 47-52.

Harrison, P. A., Vanhinsbergh, D. P., Fuller, R. J. and Berry, P. M. (2003) Modelling climate change impacts on the distribution of breeding birds in Britain and Ireland. J. Nat. Conserv. 11: 31-42.

Hermansen, J. S., Saether, S. A., Elgvin, T. O., Borge, T., Hjelle, E. and Saetre, G.-P. (2011) Hybrid speciation in sparrows I: phenotypic intermediacy, genetic admixture and barriers to gene flow. Mol. Ecol. 20: $3812-3822$.

Johnston, A., Newson, S. E., Risely, K., Musgrove, A. J., Massimino, D., Baillie, S. R. and Pearce-Higgins, J. W. (2014) Species traits explain variation in detectability of UK birds. Bird Study 61: 340-350.

Kafi, F., Hanane, S., Bensouilah, T., Zeraoula, A., Brahmia, H. and Houhamdi, M. (2015) Les facteurs déterminant le succès de la reproductions des Tourterelles des bois (Streptopelia turtur) dans un milieu agricole Nord-Africain. Rev. Écol. (Terre Vie) 70: 271-279.
Keating, K. A. and Cherry, S. (2004) Use and interpretation of logistic regression in habitat-selection studies. J. Wildlife Manage. 68: 774-789.

Krebs, C. J. (1999) Ecological methodology. 2nd ed. Menlo Park: Benjamin/Cummings.

Legendre, P. and Legendre, L. (1998) Numerical ecology. 2nd ed. Amsterdam, NL: Elsevier.

MacKenzie, D. I., Nichols, J. D., Royle, A. J., Pollock, K. H., Bailey, L. L. and Hines, J. E. (2006) Occupancy estimation and modeling: inferring patterns and dynamics of species. Boston (US): Elsevier.

Manly, B. F. J., McDonald, L. L., Thomas, D. L., Mcdonald, T. L. and Erickson, W. P. (2002) Resource selection by animals: statistical design and analysis for field studies. 2nd ed. Dordrecht: Kluwer Academic Publishers.

Mansouri, I., Al-Sadoon, M. K., Rochdi, M., Paray, B. A., Dakki, M. and Elghadraoui, L. (2019) Diversity of feeding habitats and diet composition in the turtle doves Streptopelia turtur to buffer loss and modification of natural habitats during breeding season. Saudi J. Biol. Sci. 26: 957-962.

Marx, M. and Quillfeldt, P. (2018) Species distribution models of European Turtle Doves in Germany are more reliable with presence only rather than presence absence data. $S c i$ Rep 8: 16898 .

Mason, C. F. and MacDonald, S. M. (2000) Influence of landscape and land-use on the distribution of breeding birds in farmland in eastern England. J. Zool. 251: 339-348.

Mikusiński, G. and Angelstam, P. (1997) European woodpeckers and anthropogenic habitat change: a review. Vogelwelt 118: 277-284.

Morrison, M. L., Marcot, B. G. and Mannan, R. W. (2006) Wildife-habitat relationships: concepts and applications. $3 \mathrm{rd}$ ed. Washington: Island Press.

Murton, R. K., Westwood, N. J. and Isaacson, A. J. (1984) The feeding habits of the Woodpigeon Columba palumbus, Stock Dove C. oenas and Turtle Dove Streptopelia turtur. Ibis 106: 174-188.

Newton, I. (2004) The recent declines of farmland bird populations in Britain: an appraisal of causal factors and conservation actions. Ibis 146: 579-600. 
Patón, D., Romero, F., Cuenca, J. and Escudero, J. C. (2012) Tolerance to noise in 91 bird species from 27 urban gardens of Iberian Peninsula. Landscape Urban Plan. 104: 1-8.

Pearce, J. and Ferrier, S. (2000) Evaluating the predictive performance of habitat models developed using logistic regression. Ecol. Model. 133: 225-245.

PECBMS (2019) State of common European breeding birds 2018. Prague: CSO.

Quinn, G. P. and Keough, M. J. (2002) Experimental design and data analysis for biologists. Cambridge: Cambridge University Press.

$\mathrm{R}$ Core Team (2019) R: A language and environment for statistical computing. Wien, Austria: $\mathrm{R}$ Foundation for Statistical Computing.

Rippa, D., Maselli, V., Soppelsa, O. and Fulgione, D. (2011) The impact of agro-pastoral abandonment on the Rock Partridge Alectoris graeca in the Apennines. Ibis 153: 721-734.

Rocha, G. and Quillfeldt, P. (2015) Effects of supplementary food on age ratios of European turtle doves (Streptopelia turtur L.). Anim. Biodiv. Conserv. 38: 11-21.

Ruiz-Suárez, N., Boada, L. D., HenríquezHernández, L. A., González-Moreo, F., Suárez-Pérez, A., Camacho, M., Zumbado, M., Almeida-González, M., del Mar Travieso-Aja, M. and Luzardo, O. P. (2015) Continued implication of the banned pesticides carbofuran and aldicarb in the poisoning of domestic and wild animals of the Canary Islands (Spain). Sci. Total Environ. 505: 1093-1099.

Rushton, S. P., Ormerod, S. J. and Kerby, G. (2004) New paradigms for modelling species distributions? J. Appl. Ecol. 41: 193-200.

Sáenz De Buruaga, M., Onrubia, A., Fernández-García, J. M., Campos, M. Á., Canales, F. and Unamuno, J. M. (2012) Breeding habitat use and conservation status of the Turtle Dove Streptopelia turtur in Northern Spain. Ardeola 59: 291-300.

Sing, T., Sander, O., Beerenwinkel, N. and Lengauer, T. (2007) Package ROCR: Visualizing the performance of scoring classifiers. Wien, Austria: www.cran.r-project.org.

Solomou, A. D. and Sfougaris, A. I. (2015) Bird community characteristics as indicators of sustainable management in olive grove ecosystems of Central Greece. J. Nat. Hist. 49: 301-325.
Sparks, T. H., Parish, T. and Hinsley, S. A. (1996) Breeding birds in field boundaries in an agricultural landscape. Agr. Ecosyst. Environ. 60: 1-8.

Suárez-Seone, S., Osborne, P. E. and Baundry, P. E. (2002) Responses of birds of different biogeographic origins and habitat requirements to agricultural land abandonment in northen Spain. Biol. Conserv. 105: 333-344.

Sutherland, W. J. (2006) Ecological census techniques: a handbook. 2nd ed. Cambridge: Cambridge University Press.

Sutherland, W. J., Newton, I. and Green, R. (2004) Bird ecology and conservation: a handbook of techniques. Oxford, New York: Oxford University Press.

Thomas, L., Buckland, S. T., Rexstad, E. A., Laake, J. L., Strindberg, S., Hedley, S. L., Bishop, J. R. B., Marques, T. A. and Burnham, K. P. (2010) Distance software: design and analysis of distance sampling surveys for estimating population size. J. Appl. Ecol. 47: 5-14.

Thompson, S., Larcom, A. and Lee, J. T. (1999) Restoring and enhancing rare and threatened habitats under agri-environment agreements: a case study of the chiltern Hills Area of Outstanding Natural Beauty, UK. Land Use Pol. 16: 93-105.

Tillé, Y. and Matei, A. (2016) Package sampling: Survey Sampling. Wien, Austria: www.cran.r-project.org.

Webster, S. and Felton, M. (1993) Targeting for nature conservation in agricultural policy. Land Use Pol. 10: 67-82.

Wilson, J. D., Morris, A. J., Arroyo, B. E. and Clark, S. C. (1999) A review of the abundance and diversity of invertebrate and plant foods of granivorous birds in northern Europe in relation to agricultural change. Agr. Ecosyst. Environ. 75: 13-30.

Yahiaoui, K., Arab, K., Belhamra, M., Browne, S. J., Boutin, J.-M. and Moali, A. (2014) Habitat occupancy by European Turtle Doves (Streptopelia turtur) in the Isser Valley, Algeria. Rev. Écol. (Terre Vie) 69: 234-246.

Zuur, A. F., Ieno, E. N. and Elphick, C. S. (2010) A protocol for data exploration to avoid common statistical problems: Data exploration. Methods Ecol. Evol. 1: 3-14.

Zuur, A. F., Ieno, E. N. and Smith, G. M. (2007) Analysing ecological data. New York: Springer Science + Business Media, LLC. 